\title{
Jarduera fisikoan oinarritutako programa batean parte hartzen duten gaixoek beren patologiaz, nutrizioaz eta bizi-ohiturez duten ezagutzaren azterketa
}

\begin{abstract}
Analysis of the knowledge that patients who are taking part in a physical activity program have about their pathology, nutrition and lifestyle.

Izaro Esain Castañares ${ }^{1}$, Montserrat Otero Parra ${ }^{2}$, Mariluz Ayora Trigero ${ }^{3}$, Juan Luis Zunzunegi Fernandez de Pinedo ${ }^{3}$, Susana Maria Gil Orozko ${ }^{1}$

${ }^{1}$ Fisioterapia, Fisiologia Departamentua. Medikuntza eta Erizaintza Fakultatea, UPV/EHU

${ }^{2}$ Heziketa Fisikoaren eta Kirolaren Departamentua. Hezkuntza eta Kirol Fakultatea, UPV/EHU

${ }^{3}$ Vitoria-Gasteiz Udaleko Kirol Departamentua. Kirol Medikuntza Zentroa. Vitoria-Gasteizko Udala

izaro.esain@ehu.eus

\section{Laburpena}

Jarduera fisikoa erregulartasunez praktikatzea eta nutrizio egoki bat izatea beharrezko bi tresna garrantzitsu dira gaixotasun askoren tratamendu eta prebentziorako. Gaixotasun horiek pairatzen dituzten pertsonek haien inguruan beharrezko ezagutza izatea ezinbestekoa da beren bizi-ohiturak era egokian aurrera eraman ditzaten. Lan honen helburua, jarduera fisikoko programa bateko partehartzaileek nutrizioaren, jarduera fisikoaren eta beren patologien inguruan duten ezagutza deskribatzea eta ezagutza hori beren egunerokotasunean praktikara eramaten duten edo ez aztertzea izan da. Horretarako, lau patologia zehatz hobetzera bideratutako jarduera fisikoko programa bateko 683 pertsonari egindako galdetegiak aztertu ziren. Batez besteko adina 58,3 $\pm 9,7$ urte izan zen, eta \%76,2 emakumezkoak izan ziren. Galdetegiak parte hartzaileek beren gaixotasunaren inguruan zuten ezagutzarekin zerikusia zuten galderez eta beren egunerokotasunean zituzten bizi-ohituren inguruko galderez osatuta zeuden. Nutrizioa ez zela garrantzitsua $\% 12 \mathrm{k}$ adierazi zuen. \% 91k adierazi zuen elikaduraren inguruko ezagutza ona zutela eta \% 83,3k baieztatu zuen elikadura egokia zutela. Ostera, \% 1,8k ez zuen gosaltzen \% 3,4 gazteen taldekoak izanik (<40 urte), \% 50,5ek otordu artean jateko ohitura zuen. Obesitatea pairatzen zutenen $\% 36,4 \mathrm{k}$ ez zuen bere pisua kontrolatzen eta hipertentsio arteriala zutenen $\% 72,9 \mathrm{k}$ gatza erabiltzen zuen bazkarietan. Parte-hartzaileek zuten ezagutzaren eta beren eguneroko bizi-ohituren artean desadostasuna ikusi zen, bai nutrizioari dagokionez baita beren patologiekin erlazioa duten beste faktore batzuei dagokienez ere. Hori dela-eta, garrantzitsua da elikadura, ariketa fisikoa eta osasun-hezkuntza heziketa-helburutzat dituzten programak hobetzea, eta mota horretako programa gehiago eskaintzea, batez ere patologiak dituzten pertsonentzat.
\end{abstract}

Gako-hitzak: Patologiak, nutrizioa, ezagutza, ohitura

\section{Abstract}

Appropriate nutrition and regular physical exercise are important tools for the prevention and treatment of many diseases. The objective of the present study was to analyze the awareness of 
people who participated in a physical exercise program regarding their disease and the benefits of nutrition and physical activity. We analyzed the questionnaires of 683 people who participated in a physical exercise program that was designed to improve 4 pathologies. Their average age was $58.3 \pm$ 9.7 years, and $76.2 \%$ of participants were women. Different questionnaires were used to assess the participants' knowledge about their own pathology, and the effect of nutrition and physical exercises on them, and to evaluate the practical implementation of that knowledge. Nutrition was considered to be not important for $12 \%$ of participants. For $91 \%$, their knowledge about food was good and 83.3\% admitted having good nutrition. However, $1.8 \%$ of participants didn't have breakfast $13.4 \%$ were young people). In addition, $50.5 \%$ had the habit of eating snacks, $36.4 \%$ of people with obesity didn't control their body weight and $72.9 \%$ of people with high blood pressure added salt to their food. Little agreement was observed between knowledge about nutrition and other factors that are associated with different pathologies and the implementation of them in everyday factor. For this reason it is important to continue to improve programs dealing with education in nutrition, physical exercise and health, basically in people with disease.

Keywords: Pathology, nutrition, knowledge, habits

Bidalia: 2018ko martxoaren 21ean.

http://doi.org/10.26876/osagaiz.1.2018.136

Onartua: 2018ko maiatzaren 16an.

\section{Sarrera}

Gaur egungo gizartean, obesitateak, hipertentsioak eta diabetesak duten garrantzia izugarria da, mundu mailan dagoen arazoa baita; alde batetik, pertsonarentzat, eta, bestetik, osasunzerbitzuentzat. OMEk (Osasunaren Mundu Erakundea) gaur egungo egoera ikusita, obesitatea XXI. mendeko epidemia garrantzitsuenen artean egongo dela adierazi du. Espainiako azken datuek adierazten dutenez, helduen \% 15ek obesitatea du eta \% 37k gainpisua, horrek adierazten du bi pertsona heldutik bat pisu arruntetik gora aurkitzen dela $(1,2)$. Obesitateak eragin zuzena dauka beste hainbat patologiatan, hala nola II motako diabetes mellitus-ean (DM2), hipertentsio arterialean (HTA), arazo kardiobaskularretan, zenbait minbizitan eta arnas arazoak agertzeko arriskua ere ekar dezake $(3,4)$. Gainera, esan beharra dago obesitatea pairatzen dutenek hiru aldiz arrisku handiagoa dutela DM2 eta HTA izateko (3).

Obesitatea elikagaien ahoratzearen eta gastu energetikoaren arteko desoreka iraunkor eta jarraituaren ondorioa da, non ahoratutako gehiegizko kaloriak ehun adiposo eran metatzen diren (5). Sindrome metabolikoak (SM) arazo kardiobaskularrak ekar ditzaketen faktoreak hartzen ditu bere barnean; esate baterako, obesitate zentrala (abdominala), anormaltasunak glukosaren metabolismoan eta tentsio arterialean (6).

OMEren arabera osasun-arloko zazpi gaixotasunetik sei elikadurari lotuta daude, baita jarduera fisiko ezarekin ere. Bestalde, bizitzan zehar pisu egoki bat mantentzea da biderik egokiena gaixotasun kronikoak eta minbizi mota batzuk ekiditeko (1).

Gainera, azken ikerketek adierazi dutenaren arabera, AEBn eta Europan obesitatearen zergati garrantzitsuena jarduera fisikorik eza da. Jarduera fisikoan aldaketa txikiak egiteak obesitatearen prebentzioan eragin nabarmena duela adierazi dute. Horretaz gain, jarduera fisikoak eragin handia dauka abdomeneko koipearen gutxitzean eta gorputz-pisuaren mantentzean (7).

Diabetesaren Ameriketako Elkarteak (DAE) jarduera fisikoak pertsona diabetikoengan duen garrantzia azpimarratzen du, horrek dakartzan onurak direla-eta. Haien gorputzaren konposizioan aldaketak sorrarazten ditu, esaterako, masa muskularraren gehikuntzak koipearen kantitatea gutxituz, eta, horrela, gaixotasunen garapena garatzeko aukerak gutxituz. Gainera, zelulari glukosa sartzen laguntzen dio, eta intsulinaren errezeptoreen sentsibilitatea handituko luke (8). 
Jarduera fisikoa egiteak efektu onuragarriak ditu hipertentsoengan, hobekuntzak ekartzen baititu gaixotasun kardiobaskularra ekar dezaketen faktoreetan (8,9). American College of Sports Medicineek (ACSM) adierazi duenaren arabera, hipertentso aktiboek eta egoera fisiko aerobiko ona dutenek hilkortasun-arrisku txikiagoa dute hipertentso sedentarioekin eta egoera fisiko baxua dutenekin alderatzen baditugu.

Elikaduraren eta nutrizioaren inguruan ezagutza ona izatea oso erabakigarria da elikaduraren kontsumoaren ohituretan (10). Logikoa da pentsatzea gaixoek zenbat eta ezagutza hobea izan nutrizioaren inguruan, gero eta ohitura hobeak izango dituztela. Aldiz, ikerketa epidemiologikoek adierazi dutenez, nahiz eta populazioa informatuta egon eta dieta osasuntsuaren oinarrizko kontzeptu basikoak izan, ezagutza horiek ez dira praktikara eramaten (10).

Arestian esan bezala, jarduera fisikoak eta elikadurak hainbat gaixotasunetan eragin handia dutela gauza jakina da, gai horren inguruan ikerlan asko publikatuta baitago, horietatik gehienak interbentzio-programak izanik (jarduera fisikoa edota dieta zehatzak ezarriz). Ostera, gaixoen ezagutza-mailaren inguruan ez dago publikatuta lan askorik. Horregatik, interesgarria izango litzateke nutrizioaren, jarduera fisikoaren eta beren patologien inguruan duten ezagutza nolakoa den jakitea; bestetik, ezagutza hori beren egunerokotasunean praktikara eramaten duten edo ez jakitea garrantzitsua da, etorkizunean emaitza horien arabera interbentzio-programa eraginkorragoak diseinatu ahal izateko.

\section{Material eta metodoak}

\subsection{Lagina}

Ikerketa honetan 683 pertsonaren galdeketak eta datuak aztertu ziren (adina 58,31 \pm 9,75 urte), 522 emakumezkoak ziren eta 163 gizonezkoak. Pertsona horiek Gasteizen 1999-2010 urte-bitartean garatu zen jarduera fisikoko programa gidatu batean parte hartu zuten. Programa horretan parte hartzeko gaixoek irizpide batzuk bete behar zituzten. Lehendabizi, Osakidetzako familia-medikuak patologia zehatz batzuk pairatzen zituztenei programaren nondik norakoa azaltzen zien eta interesatuta zeudenei errezeta moduko bat ematen zien, kirol-zentroko medikuarengana hurbiltzeko. Mediku horrek elkarrizketa bat izaten zuen haiekin, haien arazoak zeintzuk ziren ezagutzeko eta era horretan haien patologia kontuan izanik, talde batera edo bestera bideratzen zituen. Programa horren helburuak hauek izan ziren: patologiak jarduera fisikoaren bitartez hobetzea, jarduera fisikoa egiteko ohitura sustatzea, zer-nolako jarduera fisiko mota egin behar zuten erakustea, eta, horrela, programa bukatzean beren kabuz jarduera fisiko egokia egiteko gai izatea. Patologiak hauek ziren: obesitatea $(n=79)$, diabetesa $(n=87)$, hipertentsioa $(n=263)$ eta lokomozio-aparatuko arazoak $(n=254)$. Programak 9 hilabeteko iraupena izaten zuen, astean ordubeteko hiru saio izanik. Saio horiek Jarduera Fisiko eta Kirolean lizentziatuak ziren pertsonek eramaten zituzten aurrera. Programan parte hartu izana inklusio-irizpide bezala soilik erabili da. Ikerketa honetan adinaz, generoaz, patologiaz, pisuaz eta altueraz gain, galdetegi batzuk aztertu ziren.

\subsection{Galdetegiak}

Lau galdetegi desberdin erabili ziren, bat patologia bakoitzeko. Galdetegi horiek ad-hoc sortutakoak izan ziren, galdera guztiak itxiak, zehatzak eta argiak izan ziren. Galdetegiok era erretrospektiboan aztertu ziren, baina denbora guztian parte-hartzaileen anonimotasuna mantenduz. Lau galdetegiek bina zati izan zituzten, lehenengo zatia kasu guztietan berdina zen, eta beste zatia espezifikoa patologia bakoitzarentzat.

Galderak hiru taldetan multzokatu ziren: lehenengo taldean, parte-hartzaileak deskribatzeko erabili ziren galderak; bigarrenean, parte-hartzaileek beren gaixotasunaren inguruan zuten ezagutzarekin zerikusia zuten galderak, eta, azkenik, parte-hartzaileek beren egunerokotasunean zituzten biziohituren inguruko galderak. 


\subsection{Analisi estatistikoa}

Datuen analisi guztiak Statistical Package for Social Sciences programaren bitartez burutu ziren (21.0 bertsioa) eta kasu guztietan adierazgarritasun estatistikoa $p<0,05$-ean ezarri zen. Batez bestekoak eta desbideratze estandarra erabili genituen, baita frekuentzia (\%) eta khi karratua ere, taldeen arteko desberdintasunak aztertzeko. Parte-hartzaileen adina kontuan izanik, hiru talde sortu genituen (11): gazteen taldea, $\leq 40$ urte; adin ertainekoen taldea, 40-65 urte; eta azkenik, nagusien taldea $\geq 65$ urte. Gorputz-masaren indizea (GMI) kalkulatu genuen [pisua (kg)/altuera2 (m)] eta hori kontuan izanik parte-hartzaileak hiru taldetan banatu genituen (4): GMI $\leq 25$, normaltasun-taldea; GMI 25-29,9, gainpisua dutenen taldea, eta $\mathrm{GMI} \geq 30$, obesitatea.

\section{Emaitzak}

Parte-hartzaile guztiak kontuan izanik, gehienak (\% 76,2) emakumezkoak izan ziren, eta gainontzekoak, gizonezkoak. Gehienak adin ertainekoak ziren $(\% 74,2)$, bigarrenik nagusiak $(\% 21,6)$, eta, azkenik, gazteak $(\% 4,2)$. Joera hori patologia guztietan errepikatu zen obesitatearen kasuan izan ezik, zeinean gazteen portzentajea pertsona nagusiena baino handiagoa izan zen (1. taula).

\begin{tabular}{lcccc}
\hline Patologiak & Gazteak & Adin ertainekoak & Nagusiak & Guztira \\
\hline Obesitatea & $9(\% 31)$ & $63(\% 12,4)$ & $7(\% 4,8)$ & 79 \\
Diabetesa & $2(\% 6,9)$ & $60(\% 11,8)$ & $25(\% 17)$ & 87 \\
HTA & $1(\% 3,4)$ & $183(\% 36,2)$ & $79(\% 53,7)$ & 263 \\
APL & $17(\% 58,6)$ & $201(\% 39,6)$ & $36(\% 24,5)$ & 254 \\
Emakumezkoak & $21(\% 72,4)$ & $390(\% 76,8)$ & $109(\% 74,1)$ & 520 \\
Gizonezkoak & $8(\% 27,6)$ & $117(\% 23,2)$ & $38(\% 25,9)$ & 163 \\
\hline
\end{tabular}

HTA: Hipertentsio arteriala; APL: Lokomozio-aparatuko arazoak.

Parentesi artean adin-talde bakoitzeko patologia eta genero bakoitzeko portzentajea.

1. taula. Parte-hartzaileen deskribapena, adin-taldeak, generoa eta patologiak kontuan izanik.

Parte-hartzaile gehienek zituzten patologiak hipertentsioa (\% 38,5) eta lokomozio-aparatuko arazoak $(\% 37,2)$ izan ziren. Banaketa hori adin ertainekoen taldean eta nagusienean agertu zen; gazteen taldean, ostera, gehienek lokomozio-aparatuko arazoak zituzten eta bigarren tokian obesitatea aurkitzen zen.

Gorputz-masaren indizeari eta generoari dagokienez, estatistikoki desberdintasun esanguratsuak $(p<0.05)$ aurkitu ziren. Gizonezkoen kasuan portzentaje altuena gainpisuan aurkitzen zen, eta emakumezkoen kasuan, ostera, obesitatean, baina bi kasuetan portzentaje baxuena normaltasunean aurkitzen zen (1. irudia). 
Emakumezkoak Gizonezkoak

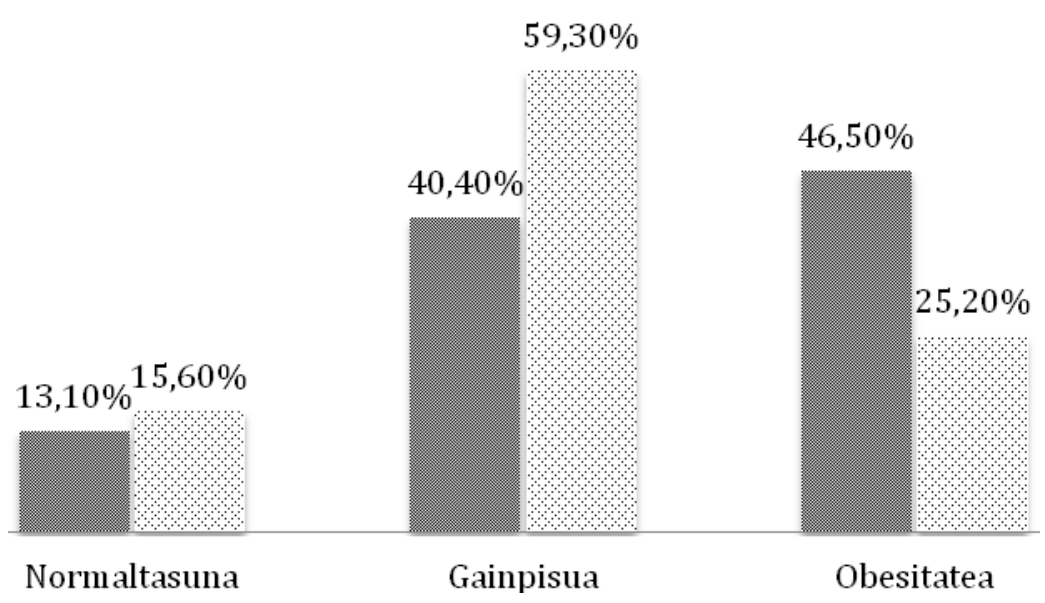

1. irudia. Gorputz-masaren indizea, generoa kontuan izanik.

$p<000,1$

Parte-hartzaileen elikaduraren ezagutzaren inguruan \% 42k ona zuela adierazi zuen eta \% 49k nahikoa zela; \% 9k, aldiz, uste zuen ez zela nahikoa. Elikaduraren garrantziaren arabera, gehienek (\% 88) erantzun zuten oso garrantzitsua zela; \% 12k, ostera, adierazi zuen elikadura ez zela garrantzitsua, ez zituela arduratzen edo batzuetan arduratzen zituela. 


\begin{tabular}{|c|c|c|c|c|c|c|c|}
\hline & & \multicolumn{3}{|c|}{ Adina $^{1}$} & \multicolumn{2}{|c|}{ Generoa } & \multirow[b]{2}{*}{ Guztira } \\
\hline & & Gazteak & $\begin{array}{l}\text { Adin } \\
\text { ertainekoak }\end{array}$ & Nagusiak & Emakumezkoak & Gizonezkoak & \\
\hline \multirow{4}{*}{ Obesitatearen eragina osasunean $^{a}$} & Ez du eragiten & 0 & $1(\% 1,6)$ & 0 & $1(\% 1,6)$ & 0 & $1(\% 1,3)$ \\
\hline & Kalteak & $9(\% 100)$ & $57(\% 93,4)$ & $5(\% 71,4)$ & $58(\% 92,1)$ & $13(\% 92,9)$ & $71(\% 92)$ \\
\hline & Onurak & 0 & $1(\% 1,6)$ & 0 & $1(\% 1,6)$ & 0 & $1(\% 1,3)$ \\
\hline & Ez daki & 0 & $2(\% 3,3)$ & $2(\% 28,6)$ & $3(\% 4,8)$ & $1(\% 7,1)$ & $4(\% 5,2)$ \\
\hline \multirow{4}{*}{ Gainpisuaren eragina HTAn $^{b}$} & Ez du eragiten & 0 & $4(\% 2,3)$ & $2(\% 2,8)$ & $5(\% 1,5)$ & $1(\% 1,5)$ & $6(\% 2,4)$ \\
\hline & Igo & $1(\% 100)$ & $146(\% 82,5)$ & $55(\% 77,5)$ & $147(\% 79,7)$ & $55(\% 84,6)$ & $202(\% 81,1)$ \\
\hline & Jaitsi & 0 & $7(\% 4)$ & $2(\% 2,8)$ & $9(\% 4,9)$ & 0 & $9(\% 3,6)$ \\
\hline & Ez daki & 0 & $20(\% 11,3)$ & $12(\% 16,9)$ & $23(\% 12,5)$ & $9(\% 13,8)$ & $32(\% 12,9)$ \\
\hline \multirow{5}{*}{ Jarduera fisikoaren eragina gluzemian $^{c}$} & Ez du eragiten & 0 & 0 & 0 & 0 & 0 & 0 \\
\hline & Gehitu & 0 & $1(\% 1,8)$ & 0 & 0 & $1(\% 3,7)$ & $1(\% 1,3)$ \\
\hline & Gutxitu & $1(\% 100)$ & $47(\% 82,5)$ & $16(\% 76,2)$ & $43(\% 82,7)$ & $21(\% 77,8)$ & $64(\% 81)$ \\
\hline & Ez daki zer den gluzemia & 0 & $3(\% 5,3)$ & 0 & $2(\% 3,8)$ & $1(\% 3,7)$ & $3(\% 3,8)$ \\
\hline & Ez daki & 0 & $6(\% 10,5)$ & $5(\% 23,8)$ & $7(\% 13,5)$ & $4(\% 14,8)$ & $11(\% 13,9)$ \\
\hline \multirow{4}{*}{$\begin{array}{llll}\text { Gainpisuaren } & \text { eragina } & \text { min } & \text { osteo- } \\
\text { artikularrean }^{d} & & & \\
1^{* *} & & & \end{array}$} & Ez du eragiten & 0 & $8(\% 4,2)$ & $3(\% 9,4)$ & $9(\% 4,7)$ & $2(\% 4,3)$ & $11(\% 4,6)$ \\
\hline & Igo & $15(\% 88,2)$ & $152(\% 80,4)$ & $22(\% 68,8)$ & $152(\% 79,6)$ & $37(\% 78,7)$ & $189(\% 79,5)$ \\
\hline & Jaitsi & 0 & $2(\% 1,1)$ & 0 & $1(\% 0,5)$ & $1(\% 2,1)$ & $2(\% 0,8)$ \\
\hline & Ez daki & $2(\% 11,8)$ & $27(\% 14,3)$ & $7(\% 21,8)$ & $29(\% 15,2)$ & $7(\% 14,9)$ & $36(\% 15,1)$ \\
\hline
\end{tabular}

2. taula. Parte-hartzaileen ezagutza beren patologien inguruan, adina eta generoa kontuan izanik.

HTA: Hipertentsio arteriala

Galdera eginda honako patologia hauek zituztenei: ${ }^{a}$ Obesitatea ${ }^{b} \mathrm{HTA},{ }^{c}$ Diabetes mellitusa eta ${ }^{\mathrm{d}}$ Lokomozio-aparatuko arazoak

${ }^{1}$ Adin-taldeen artean desberdintasunak

$* * p<0,01$ 
Parte-hartzaile gehienek (\% 92) adierazi zuten obesitatea osasunerako kaltegarria dela; \% 8k, aldiz, erantzun hauetako bat eman zuen: «ez du eragiten», "onurak dakartza» edo «ez daki nola eragiten duen» (2. taula).

Hipertentsio arteriala (HTA) pairatzen zutenen artean, \% 12,9k ez zekien nola eragiten duen gainpisuak HTAn, eta \% 6k esan zuen gainpisuak ez daukala inolako eraginik HTAn edo jaitsi egiten duela.

Beste alde batetik, diabetesa zutenen \% 13,9k ez zekien ariketa fisikoak zer eragin duen gluzemian, \% 3,8k ez zekien hitz horren esanahia, eta \% 1,3k erantzun zuen handitu egiten duela. Jarduera fisikoak gluzemian nola eragiten duen ez zekiten parte-hartzaileen artean, pertsona nagusi gehiago $(\% 23,5)$ ageri ziren adin ertainekoak $(\% 10,5)$ baino.

Lokomozio-aparatuko arazoak dituztenei gainpisuak min osteo-artikularrean nola eragin dezakeen galdetzean, \% 15ek ez dakiela nola eragiten duen erantzun zuen, eta portzentaje hori nagusien kasuan handitu egiten zen $\% 21$,8raino. Gainera, nagusien \% 9,4k adierazi zuen pisuak ez duela inolako eraginik minari dagokionez, baita adin ertainekoen $\% 4,2 k$ ere.

Deigarria da lokomozio-aparatuko arazoak dituzten pertsonen erantzunak adinak aurrera egin ahala portzentaje baxuagoan izan direla egokiak, hori estatistikoki esanguratsua izanik $(p<0,01)$. 


\begin{tabular}{|c|c|c|c|c|c|c|c|c|c|c|c|}
\hline & & \multicolumn{3}{|c|}{ Adina $^{1}$} & \multicolumn{2}{|c|}{ Generoa $^{2}$} & \multicolumn{4}{|c|}{ Patologiak $^{3}$} & \multirow[b]{2}{*}{ Guztira } \\
\hline & & Gazteak & $\begin{array}{l}\text { Adin } \\
\text { ertainekoak }\end{array}$ & Nagusiak & Emakumezkoak & Gizonezkoak & Obesitatea & Diabetesa & HTA & $\overline{A P L}$ & \\
\hline Pisuaren kontrola & Bai & $20(\% 69)$ & $361(\% 72,1)$ & $110(\% 76,4)$ & $373(\% 73)$ & $118(\% 72,4)$ & $49(\% 63,6)$ & $73(\% 84,9)$ & $199(\% 76,2)$ & $169(\% 67,9)$ & $491(\% 72,8)$ \\
\hline $3^{* *}$ & Ez & $9(\% 31)$ & $140(\% 27,9)$ & $34(\% 23,6)$ & $138(\% 27)$ & $45(\% 27,6)$ & $28(\% 36,4)$ & $12(\% 15,1)$ & $62(\% 23,8)$ & $80(\% 32,1)$ & $183(\% 27,2)$ \\
\hline Nork eramaten duen & Norberak & $16(\% 84,2)$ & $184(\% 55,5)$ & $56(\% 53,8)$ & $190(\% 55,9)$ & $66(\% 57,9)$ & $25(\% 55,6)$ & $19(\% 28,4)$ & $84(\% 45,4)$ & $128(\% 82,1)$ & $256(\% 56,4)$ \\
\hline kontrolaren pisua & Espezialistak & $2(\% 10,5)$ & $129(\% 39)$ & $44(\% 42,3)$ & $132(\% 38,8)$ & $43(\% 37,7)$ & $16(\% 35,6)$ & $43(\% 64,2)$ & $93(\% 50,3)$ & $22(\% 14,1)$ & $175(\% 38,5)$ \\
\hline $3^{* * *}$ & Dietistak & $1(\% 5,3)$ & $18(\% 5,4)$ & $4(\% 3,8)$ & $18(\% 5,3)$ & $5(\% 4,4)$ & $4(\% 8,9)$ & $5(\% 7,5)$ & $8(\% 4,3)$ & $6(\% 3,8)$ & $23(\% 5,1)$ \\
\hline Lo-ordu kopurua & $<7$ ordu & $7(\% 25)$ & $266(\% 54,2)$ & $69(\% 50,4)$ & $275(\% 55)$ & $67(\% 42,9)$ & $35(\% 46,1)$ & $34(\% 42,5)$ & $142(\% 56,8)$ & $131(\% 52,6)$ & $342(\% 52,1)$ \\
\hline \multirow[t]{2}{*}{$1^{*}, 2^{*}$} & $7-8$ ordu & $17(\% 60,7)$ & $190(\% 38,7)$ & $52(\% 38)$ & $186(\% 37,2)$ & $73(\% 46,8)$ & $31(\% 40,8)$ & $40(\% 50)$ & $89(\% 35,6)$ & $98(\% 39,4)$ & $259(\% 39,5)$ \\
\hline & $>8$ ordu & $4(\% 14,3)$ & $35(\% 7,1)$ & $16(\% 11,7)$ & $39(\% 7,8)$ & $16(\% 10,3)$ & $10(\% 13,2)$ & $6(\% 7,5)$ & $19(\% 7,6)$ & $20(\% 8)$ & $55(\% 8,4)$ \\
\hline Loaren kalitatea & Ona & $10(\% 35,7)$ & $167(\% 34)$ & $58(\% 42,3)$ & $160(\% 32,1)$ & $75(\% 47,5)$ & $22(\% 28,6)$ & $33(\% 41,3)$ & $97(\% 38,8)$ & $83(\% 33,5)$ & $235(\% 35,8)$ \\
\hline \multirow[t]{2}{*}{$2 * *, 3 *$} & $\begin{array}{l}\text { Hala- } \\
\text { holakoa }\end{array}$ & $17(\% 60,7)$ & $226(\% 46)$ & $55(\% 40,1)$ & $240(\% 48,2)$ & $58(\% 36,7)$ & $44(\% 57,1)$ & $31(\% 38,8)$ & $11(\% 46,4)$ & $106(\% 42,7)$ & $298(\% 45,4)$ \\
\hline & Txarra & $1(\% 3,6)$ & $98(\% 20)$ & $24(\% 17,5)$ & $98(\% 19,7)$ & $25(\% 15,8)$ & $11(\% 14,3)$ & $16(\% 20)$ & $37(\% 14,8)$ & $59(\% 23,8)$ & $123(\% 18,8)$ \\
\hline \multirow[t]{4}{*}{ Edaten duten ur kantitatea } & $<2$ baso & $2(\% 7,1)$ & $62(\% 12,4)$ & $19(\% 13,8)$ & $68(\% 13,4)$ & $15(\% 9,5)$ & $12(\% 15,4)$ & $7(\% 8,8)$ & $23(\% 9,5)$ & $40(\% 15,8)$ & $83(\% 12,5)$ \\
\hline & 2-4 baso & $8(\% 28,6)$ & $184(\% 36,8)$ & $59(\% 42,8)$ & $194(\% 38,3)$ & $57(\% 36,1)$ & $24(\% 30,8)$ & $37(\% 46,3)$ & $94(\% 37,2)$ & $95(\% 37,5)$ & $251(\% 37,7)$ \\
\hline & 4-6 baso & $11(\% 39,3)$ & $156(\% 31,3)$ & $33(\% 23,9)$ & $151(\% 29,8)$ & $49(\% 31)$ & $27(\% 34,6)$ & $19(\% 23,8)$ & $83(\% 32,8)$ & $71(\% 28,1)$ & $200(\% 30,1)$ \\
\hline & $>6$ baso & $7(\% 25)$ & $97(\% 19,4)$ & $27(\% 19,6)$ & $94(\% 18,5)$ & $37(\% 23,4)$ & $15(\% 19,2)$ & $17(\% 21,3)$ & $52(\% 20,6)$ & $47(\% 18,6)$ & $131(\% 19,7)$ \\
\hline $\begin{array}{l}\text { Jarduera fisiko mota } \\
\text { programatik kanpo }\end{array}$ & $\begin{array}{l}\text { Sedentarioa } \\
\text { Moderatua }\end{array}$ & $\begin{array}{l}2(\% 25) \\
6(\% 75)\end{array}$ & $\begin{array}{r}8(\% 13,8) \\
48(\% 82,8)\end{array}$ & $\begin{array}{l}2(\% 28,6) \\
5(\% 82,8)\end{array}$ & $\begin{array}{c}6(\% 10) \\
52(\% 86,7)\end{array}$ & $\begin{array}{l}6(\% 46,2) \\
7(\% 53,8)\end{array}$ & & & & & $\begin{array}{l}12(\% 16,4) \\
59(\% 80,8)\end{array}$ \\
\hline $2^{* *}$ & Intentsua & 0 & $2(\% 3,4)$ & 0 & $2(\% 3,3)$ & 0 & & & & & $2(\% 2,7)$ \\
\hline
\end{tabular}

3. taula. Parte-hartzaileen eguneroko bizi-ohiturak, adina, generoa eta patologia kontuan izanik.

HTA: Hipertentsio arteriala; APL: Lokomozio-aparatuko arazoak; AF: Ariketa fisikoa ${ }^{*} p<0,05 ;{ }^{*} p<0,01 ; * * *<0,001$

1 adin-taldeen arteko desberdintasunak; 2 generoen arteko desberdintasunak; 3 patologia desberdinen arteko desberdintasunak, ${ }^{a}$ Obesitatea zuten subjektuak 


\begin{tabular}{|c|c|c|c|c|c|c|c|c|c|c|c|}
\hline & & \multicolumn{3}{|c|}{ Adina $^{1}$} & \multicolumn{2}{|c|}{ Generoa $^{2}$} & \multicolumn{4}{|c|}{ Patologiak $^{3}$} & \multirow[b]{2}{*}{ Guztira } \\
\hline & & Gazteak & $\begin{array}{l}\text { Adin } \\
\text { ertainekoak }\end{array}$ & Nagusiak & Emakumezkoak & Gizonezkoak & Obesitatea & Diabetesa & HTA & APL & \\
\hline Gosaltzen duten & Bai & $28(\% 96)$ & $495(\% 98,4)$ & $143(\% 97,7)$ & $510(\% 98)$ & $156(\% 96,3)$ & $78(\% 100)$ & $85(\% 100)$ & $254(\% 96,9)$ & $248(\% 98,4)$ & $666(\% 98,2)$ \\
\hline 2* & Ez & $1(\% 3,4)$ & $8(\% 1)$ & $3(\% 2,1)$ & $6(\% 1,2)$ & $6(\% 3,7)$ & 0 & 0 & $8(\% 3,1)$ & $4(\% 1,6)$ & $12(\% 1,8)$ \\
\hline Otordu artean jaten duten & Bai & $18(\%$ 62,1) & $270(\% 54,2)$ & $50(\% 35,2)$ & $268(\% 52,9)$ & $70(\% 43,2)$ & $38(\% 49,4)$ & $44(\% 51,8)$ & $126(\% 48,8)$ & $129(\% 52)$ & $338(\% 50,5)$ \\
\hline $1^{* * *}, 2^{*}$ & $\mathrm{Ez}$ & $11(\% 37,9)$ & $228(\% 45,8)$ & $92(\% 64,8)$ & $239(\% 47,1)$ & $92(\% 56,8)$ & $39(\% 50,6)$ & $41(\% 48,2)$ & $132(\% 51,2)$ & $119(\% 48)$ & $331(\% 49,5)$ \\
\hline Elikadura egokia & Bai & $20(\% 71,4)$ & $398(\% 81,7)$ & $127(\% 91,4)$ & $404(\% 81,5)$ & $141(\% 89,2)$ & $53(\% 72,6)$ & $65(\% 78,3)$ & $219(\% 84,2)$ & $207(\% 87,3)$ & $545(\% 83,3)$ \\
\hline $1 * *, 2 *, 3 *$ & Ez & $8(\% 28,6)$ & $89(\% 18,3)$ & $12(\% 8,6)$ & $92(\% 18,5)$ & $17(\% 10,8)$ & $20(\% 27,4)$ & $18(\% 21,7)$ & $41(\% 15,8)$ & $30(\% 12,7)$ & $109(\% 16,7)$ \\
\hline Jatorduetan $^{\mathrm{a}}$ & Batzuetan & $1(\% 100)$ & $75(\% 41,9)$ & $28(\% 39,4)$ & $80(\% 43)$ & $24(\% 36,9)$ & & & & & $104(\% 41,4)$ \\
\hline $2^{* * *}$ & Inoiz & 0 & $47(\% 26,3)$ & $21(\% 29,6)$ & $39(\% 21)$ & $29(\% 44,6)$ & & & & & $68(\% 27,1)$ \\
\hline
\end{tabular}

4. taula. Parte-hartzaileen elikaduraren inguruko iritzia, adina, generoa eta patologia kontuan izanik.

HTA: Hipertentsio arteriala; APL: Lokomozio-aparatuko arazoak; AF: Ariketa fisikoa ${ }^{*} p<0,05 ;{ }^{* *} p<0,01 ;{ }^{* * *} p<0,001$

1 adin-taldeen arteko desberdintasunak; 2 generoen arteko desberdintasunak; 3 patologia desberdinen arteko desberdintasunak, ${ }^{a}$ Hipertentsio arteriala zuten subjektuak 
Aurreko taulan ikus daitekeenez (3. taula), parte-hartzaileen $\% 27,2 \mathrm{k}$ ez zuen pisuaren kontrolik eramaten, portzentaje hori obesitatea zutenen artean altuagoa zen $(\% 36,4)$ diabetikoen portzentajearekin alderatuta $(\% 15,1)$, desberdintasun estatistikoak aurkitu direlarik $(p<0,01)$.

Pisuaren kontrola nork eramaten zuen aztertzen badugu, obesitatea zutenen $\% 55,6 \mathrm{k}$ bere kabuz pisatzen zuen bere burua eta HTA zutenen \% 45,4k. Lokomozio-aparatuko arazoak zituztenen kasuan, $\% 82$,1ek bere kabuz pisatzen zuen bere burua; diabetikoen $\% 64,2 \mathrm{ri}$, ostera, espezialistak kontrolatzen zion pisua.

Lo egiten zuten ordu kopuruari eta loaren kalitateari erreparatzen badiegu, ikus dezakegu partehartzaileen erdiek 7 ordu baino gutxiago egiten zutela lo; \%55,1 emakumezkoak eta \% 42,9 gizonezkoak izanik. Loaren kalitateari dagokionez, gizonezkoen \%47,5ena ona izan zen eta emakumezkoen kasuan \%32,1ena. Zazpi ordutik behera lo egiten zutenen portzentaje baxuena gazteen taldeari egokitu zitzaion $(p<0.05)$. Generoari dagokionez, loaren kalitate hala-holakoa edo txarra emakumezkoek izan zuten gizonezkoekin konparatuz $(p<0,01)$, eta patologiei dagokienez, obesitatea pairatzen zuten pertsonek lo-kalitate okerragoa zuten $(p<0,05)$.

Partaideen \% 67,8k egunean 2-6 baso ur edaten zituela adierazi zuen, bestalde \% 12,5ek bi baso baino gutxiago edaten zuela. Gazteak ziren ur gehien edaten zutenak, $\% 25 \mathrm{ek}$ sei ur baso baino gehiago edaten zituen eta \% 40k 4-6 baso bitartean. Nagusien kasuan, ostera, \% 24k 4-6 baso edaten zituen egunean.

Obesitatea pairatzen zuten partaideek programatik kanpo egiten zuten jarduera fisikoa aztertzen badugu, emakumezkoen \% 10 eta gizonezkoen \% 46,2 sedentarioak ziren. Gainera, emakumezkoen $\% 3,3 \mathrm{k}$ soilik egiten zuen intentsitate altuko jarduera, eta gizonezko bakar batek ere ez.

Gosaltzen ez zutenen kopurua \% 1,8koa izan zen, portzentajerik altuena gazteena izanik $(\% 3,4)$. Gosaltzen ez zuten gizonezkoen portzentajea handiagoa izan zen emakumezkoena baino (\% 3,7 vs. $\% 1,2)$ (4. taula).

Parte-hartzaileen erdiek otordu artean jateko ohitura zuten, gazteak izanik gehien egiten zutenak $(\% 62,1)$ eta nagusiak gutxien $(\% 35,2)$. Generoari dagokionez, emakumezkoen $\% 52,9 \mathrm{k}$ jaten zuen otordu artean, eta gizonezkoen kasuan, ostera, \% 43,2k.

HTA zuten pertsonen gatzaren eguneroko kontsumoari dagokionez, \% 31,5ek adierazi zuen beti erabiltzen zuela, eta \% 41,4k batzuetan. Gizonezkoen kasuan, $\% 44,6 \mathrm{k}$ adierazi zuen ez zuela sekula mineral hori erabiltzen, eta emakumezkoen kasuan, portzentaje hori erdira jaisten zen (\% 21).

Azkenik, parte-hartzaileen \% 16,7k esan zuen bere elikadura ez zela egokia eta portzentaje horrek gora egin zuen gazteen artean \% 28,6 izanik ( $p<0,001)$, emakumezkoen artean $\% 18,5$ ( $p<0,01)$, obesitatea zutenen artean $\% 27,4$ eta diabetesa zutenen artean $\% 21,7$.

\section{Eztabaida}

Nutrizio egokiaren, jarduera fisikoaren eta ohitura osasuntsuen onurak aurretik egiaztatuak daude, alabaina ikerketa gutxik aztertu dute pertsonek duten ezagutza eta nola eramaten duten praktikara beren egunerokotasunean. Hori dela-eta, patologia desberdinak dituzten 683 pertsonaren galdetegiak aztertu ziren.

Lehenengo eta behin esan dezagun programan parte hartu zuten emakumezkoen kopurua gizonezkoena halako hiru izan zela, baita adin-talde guztietan eta patologietan ere. Aldiz, Romero, Carrasco, Sañudo eta Chacónek (2010) azaldu zuten, oro har, gizonezkoek proportzionalki astean zehar jarduera fisiko gehiago egiten dutela emakumezkoek baino (12).

Mora, Villalobos, Araya, eta Ozolsek (2004) esan zuten osasuna zela jarduera fisikoa egitearen arrazoi nagusia bai gizonezkoentzat bai emakumezkoentzat, baina badirudi jarduera fisiko gidatua 
erakargarriagoa dela emakumezkoentzat (13); beste autore batzuek ere diabetesaren hezkuntzarako programa batean emakumezkoen asistentzia altuagoa ikusi zuten (14). Interesgarria izango litzateke aztertzea ea adin eta patologia antzekoa duten gizonezkoek programa gidatuetara joan beharrean beste mota bateko ariketa fisikoren bat egiten duten. Horrela balitz, esfortzua egin beharko litzateke gizonezkoak mota honetako programetara joatera animatzeko.

Ikerketa honetako partaide gehienak 40 eta 65 urte bitartekoak ziren, hori ulergarria da kontuan hartzen badugu programan zeuden patologiak adin ertainekoengan nagusitzen direla batez ere.

Talde guztia kontuan hartuta, HTA eta lokomozio-aparatuko arazoak proportzio berdinean zeudela sumatu zen. Gazteek lokomozio-aparatuko arazoak jasaten zituzten gehienbat eta bigarren tokian obesitatea. Hori horrela izan daiteke obesitatea gero eta gehiago ageri baita adin goiztiarretan, eta horrek bizitzan zehar beste patologia batzuk izateko arriskua gehitzen du, hala nola HTA eta diabetesa (1,2). Aldiz, adin ertainekoen eta nagusien taldean HTA pairatzen zuten pertsonak gailentzen ziren, hori normala da, HTA gure gizarteko nagusien herenak sufritzen baitu eta beste herena prehipertentsoak dira (15).

Parte-hartzaile gehienak pisu egokitik gora zeuden, eta programa horretan tratatzen ziren patologiak kontuan hartzen baditugu, espero izateko emaitza da, patologia guztiek erlazio zuzena baitute obesitatearekin. Beraz, ikerketa honetan lortutako emaitzak gizartearen joerekin bat datoz, zeren Espainian bi pertsonatik bat pisu egokitik gora aurkitzen baita $(1,2)$.

Mazalin, Protulipac, Sonicki eta Reiner-ek (2015) baieztatu zuten arrisku-faktoreen ezagutza izatea erabakigarria zela gaixotasun kardiobaskularrak ulertu eta prebenitzeko (16). Horretaz gain, American Heart Association-ek (AHA) nabarmendu zuen subjektuen hezkuntzaren garrantzia haien osasuna eta bizi-kalitatea hobetzeko (17). Hala ere, subjektuek arrisku-faktoreen eta beren patologien inguruan duten ezagutzaren inguruko publikazioak urriak dira gaur egun.

Ikerketa honetan nutrizioarekin erlazionatutako lau aldagai aztertu ziren: garrantzia, ezagutzaren inguruan zuten pertzepzioa, haien elikaduraren inguruko iritzia eta HTA zutenei gatzaren erabileraren inguruan galdetu zitzaien.

Haien patologietan elikadurak zuen garrantzia galdetzean kopuru adierazgarri batek erantzun zuen ez ziela axola, garrantzi gutxi zuela edo noizbehinka axola ziela. Deigarria da ikerketa honetako partehartzaileek nutrizioari ematen dioten garrantzirik eza, kontuan izanda horrek gaixotasun kronikoekin duen garrantzia, zeren pisu egoki batean mantentzeak gaixotasun kroniko eta minbizi batzuk saihesten baititu (18). Izan ere, OMEk dioenez, 7 gaixotasunetik 6 erlazionatuta daude nutrizioarekin eta jarduera fisikorik ezarekin.

Bestetik, elikaduraren inguruan zuten ezagutzaren inguruan gehiengoak (\% 91) esan zuen ona edo nahikoa zutela; portzentaje baxuagoak (\% 83), aldiz, esan zuen elikadura egokia zutela. Beren elikadurari buruzko iritzia galdetu zitzaienean, gazteen herenak adierazi zuen ez zuela elikadura onik; portzentaje hori, aldiz, asko gutxitzen zen nagusien kasuan, \% 8,6koa izanik. Ezberdintasun handi horren arrazoi nagusiak bi izan daitezke: lehenengoa, gaur egungo gizartean jendeak, eta batez ere gazteek, gero eta denbora gutxiago eskaintzen diotela eguneroko jatekoa prestatzeari; horrela, janari azkarra edo aurrekoz prestatua jatea gero eta arruntagoa da. Eta janari mota horrek, obesitateari dagokionez, paper garrantzitsua hartzen du (19). Bigarrena izan daiteke gazteek ezagutza edo informazio handiagoa izatea eta hobeto jakitea zer den elikadura ona, bai eta beren jatekoarekin kritikoagoak izatea ere.

National Institute of Aging eta American Heart Association-en jarraibideen arabera, jatorduetan gatzaren erabilera kontrolatzea da neurririk egokiena, eguneko 1.500 miligramo izanik aholku gomendagarriena. Datu hori hainbat ikerketak babesten dute, gatzaren gutxitzeak presio arteriala gutxitzen duela ikusi baitute $(20,21)$, eta gainera arratoietan ikusi dute gatz gehiegi erabiltzea gaixotasun kardiobaskularren arrisku-faktore garrantzitsua dela (21). Baina ikerketa honetako hipertentso gehienek (\% 73) gatza beti edo batzuetan erabiltzen zuten; azpimarragarria da talde 
horretan gehienek (\% 84) adierazi zutela elikadura egokia zutela. Correia eta lankideek (2014) ikusi zuten subjektuek aholkatutako sodioaren kontsumoa gainditu egiten zutela, jaten zituzten elikagai industrializatuengatik eta jatekoari gatza gehitzeko ohituragatik (22).

Beraz, ondorioztatu daiteke gatzaren inguruan hipertentsioa duten pertsonek ezagutza falta dutela, jatekoei botatzen dieten gatz kopuruari behar beste garrantzirik ematen ez baitiote. Horrenbestez, interbentzio-programak edo estrategia desberdinak erabili beharko lirateke gaixoen ohitura horiek aldatu ahal izateko.

Diabetesa pairatzen zutenen artean, deigarriena da \%3,8k ez zekiela zer zen gluzemia; horren arrazoiak bi izan daitezke. Alde batetik, posible da pertsona horiek hitz hori ez ezagutzea. Adibidez, haiekin harremana zuten medikuek edo erizainek hitz hori ez zutelako erabiltzen. Eta bestetik, arazoa egon daiteke odoleko glukosa-maila eta haren garrantzia zein den ez dakitelako. Gure ustez datu horiek pentsatzera eraman behar gaituzte, batez ere mota horretako pertsonekin lan egiten dugunok, zeren kasu askotan erakutsi nahi diegu, adibidez, nola eragiten duen jarduera fisikoak haien patologian, baina garrantzitsuagoa da haien patologia ezagutzea (14).

Ikerketa honetan egunerokotasuneko ohitura batzuk aztertu ziren, haien ezagutza praktikara nola eramaten zuten jakiteko.

Parte-hartzaileen \% 1,8k ez zuen gosaltzen, batez ere gizonezko gazteek, nahiz eta autore batzuen ustetan ez gosaltzeko ohitura emakume gazteen artean zabalduago dagoen (23). Gainera kontuan izan behar dugu gosaria beharrezko otordua dela, eguneko energiaren \% 20-25 bertan ahoratu beharko bailitzateke (23). Watanabe eta lankideek (2014) adierazi zutenez, gosaltzen ez duten nerabeetan obesitatea gehiago ageri da (24).

Pisuarekin zuzenki erlazionatuta dauden patologietan horren kontrola izateak garrantzi handia dauka (25). Hala ere, taldearen herenak ez zuen bere burua pisatzen, eta portzentaje hori obesitatea pairatzen zutenen artean handitzen zen. Horren arrazoia inpaktu psikologikoarekin erlazionatuta egon daiteke, zeren pertsona horiek beren burua pisatzean eta beren pisua ikustean, agian momentu horretan duten arazoaz jabetu daitezke.

Bestetik, obesitatea gizartean ongi baloratuta ez dagoela kontuan hartzen badugu, horrek ere sentimendu hori handi dezake (26). Obesitatea zutenen kasuan erdiek adierazi zuten berek eramaten zutela pisuaren kontrola, kasu horretan egokiena espezialista batek jarraipena egitea izango litzakeelarik.

Loaren iraupenak osasunean eta funtzionaltasunean eragina dauka (27). Autore batzuek diote helduek gutxi gorabehera 7 ordu behar dituztela eta nagusitzen joan ahala gutxitzera joan ohi dela beharrezko ordu kopurua (28). Ikerketa honetan, ostera, adin ertainekoak izan ziren lo-ordu gutxien egiten zutenak. Loaren kalitateari dagokionez, emakumeak izan ziren kalitate txarragoa zutela adierazi zutenak, eta hori bat dator beste autore batzuek diotenarekin, esaten baitute emakumezkoek loaren alterazio gehiago izaten dituztela edo loaren falta handiagoa dutela gizonek baino (29).

Hidratazioari dagokionez, jakina da ura beharrezko substantzia dela organismoaren funtzionamendurako honen erreakzio eta aldaketa guztietan parte hartzen baitu (30). Nagusietan urak garrantzi gehiago dauka, pertsona horien hidratazio-egoera arriskutsuagoa baita. Gainera adinarekin gutxitu egiten da gorputzeko ur kantitatea, gizonezkoetan $\% 60$ eta emakumezkoetan \% 50 gutxiago izanik. Esan ohi da pertsona normal batek egunean 2-2,5 litro edari edan beharko lituzkeela (10-12 basokada) (18,30). Ikerketa honetan nagusien kasuan \% 24k gutxi gorabehera 4-6 baso bitartean edaten zuen. Beraz, interesgarria da pertsona nagusiak ura edatera estimulatzea, are gehiago kasu honetan, jarduera fisikoko programa batean parte hartzen baitaude.

Obesitatea pairatzen zutenen \% 83k programatik kanpo ariketa fisikoa egiten zuen, eta horrek jarduera fisikoarekiko kontzientzia positiboa adierazten du. Ikerketa honetako emaitzak Kroazian 883 
pertsonarekin egindako ikerketan lorturako emaitzen aurka doaz, ikusi baitzuten ikerketa horretako parte-hartzaileek pertzepzio urria zutela ariketa fisikoak izan zezakeen garrantziaz gaixotasun kardiobaskularrak saihesteko unean. Izan ere, bertako partaideek adierazi zuten arazo kardiobaskularretan arrisku-faktore garrantzitsuena tentsio arterial altua izatea zela eta garrantzia gutxienekoa jarduera fisikoa (30).

\section{Ondorioak}

Ikerketa honek konfirmatzen du emakumezkoek gizonezkoek baino afinitate gehiago dutela patologiak hobetzera bideratutako jarduera fisikoko programekin. Interesgarria izango litzateke ikertzea ea gizonezkoek beste ariketa fisiko edo kirol mota bat egiten duten edo sedentarioagoak diren, zeren ikusi baita obesitatea duten pertsonen artean gizonezkoak sedentarioagoak direla. Beraz, agian programa edo aktibitate desberdinak eskaini beharko lirateke haien jarduerarik eza gutxitzeko.

Bestetik, eguneroko bizi-ohituren eta haien ezagutzaren artean izugarrizko desoreka ikusi zen. Arrazoi hori dela-eta, oso garrantzitsua da nutrizio-eremuko heziketaren, jarduera fisikoaren eta osasunaren inguruaren dauden programak hobetu eta jarraipena izatea, batez ere patologiak dituzten pertsonen artean.

\section{Mugak eta proposamenak}

Ikerlan honen mugarik handiena izan zen erabilitako galde-sortak ez direla bibliografian aurkitzen. Gainera, ez zen inolako neurketa objektiborekin egin. Beraz, argi dago galdetegien bidez jasotako informazioa subjektiboa dela eta hori kontuan izan behar da artikulua irakurtzeko unean.

Beraz, kontuan izanik patologiak dituzten pertsonek beren patologia ez dutela behar beste ezagutzen, haiekin harremanetan dauden espezialistek hori kontuan izan beharko lukete eta ahal den neurrian denbora pixkatxo bat eskaini beren patologia gehiago ezagutu dezaten.

Bestalde, patologia desberdinei bideratutako programa terapeutikoak, hau da, jarduera fisikoa eta nutrizio-programak oso urriak dira gure inguruan eta horiek sustatzea ondo egongo litzake. Gainera, komenigarria ikusten dugu jarduera fisikoan adituak diren pertsonak patologia hauek dituzten pertsonentzat eskuragarri izatea osasun-zentro edo ospitaletan, kasu bakoitza aztertu ondoren aholkuak eta gomendioak eman ahal izateko.

\section{Eskerrak}

Juan Luis Zunzunegui† medikuari eta Malu Ayora erizainari eskertu nahi genieke lan hau egiteko beharrezko datuak jasotzeko baimena emateagatik eta une oro izandako jarrerarengatik. Lan hau Eusko Jaurlaritzaren doktoratu aurreko beka bati esker eraman ahal izan da aurrera (PRE_2014_1_137).

\section{Erreferentzia bibliografikoak}

1 Ballesteros Arribas JM, Dal-Re Saavedra M, Pérez Farinós N, Villar Villalba C. La estrategia para la nutrición, actividad física y prevención de la obesidad (Estrategia NAOS). Rev Esp Salud Pública. 2007;81:443-449.

2 Szer G, Kovalskys I, De Gregoria MJ. Prevalencia del sobrepeso, obesidad y su relación con hipertensión arterial y centralización del tejido adiposo en escolares. Arch Argent Pediatr. 2010;108(6):492-498. 
3 Carrasco F, Moreno M, Irribarra V, Rodríguez L, Martin MA, Alarcón A, Mizón C, Echenique C, Saavedra $\mathrm{V}$,Pizarro T, Atalah E. Evaluación de un programa piloto de intervención en adultos con sobrepeso u obesidad, en riesgo de diabetes. Rev Méd Chile. 2008;136:13-21.

4 Fock KM, Khoo J. Diet and exercise in management of obesity and overweight. J Gastroenterol Hepatol. 2013 Dec;28 Suppl 4:59-63.

5 Bastos, AA, González Boto, R, Molinero González, O, Salguero del Valle, A. Obesidad, nutrición y actividad física [Internet]. Rev Int Med Cienc Act Fís Deporte. 2005 [Kontsulta: 2018-04-22]; 5(18):140-152.

Eskuragarri: http://www.redalyc.org/articulo.oa?id=54221982005

6 Bello Rodríguez B, Sánchez Cruz G, Campos Ferreira Pinto A, Báez Pérez EG, Fernández Morín J, Achiong Estupiñan F. Síndrome Metabólico: un problema de salud con múltiples definiciones. Rev Méd Electrón [Internet]. 2012 Mar-Abr [Kontsulta. 2018-04-22]; 34(2). Eskuragarri:

http://www.revmatanzas.sld.cu/revista\%20medica/ano\%202012/vol2\%202012/tema09.htm

7 Tárraga Marcos ML, Rosich N, Panisello Royo JM, Gálvez Casas A, Serrano Selva JP, RodríguezMontes JA, Tárraga López PJ. Eficacia de las estrategias de motivación en el tratamiento del sobrepeso y obesidad. Nutr Hosp. 2014;30(4):741-748.

8 Márquez Rosa S, Rodrígurez Ordaz J, De abajo Olea S. Sedentarismo y salud: efectos beneficiosos de la actividad física[Internet]. Apunts Educ Fís Deportes. 2006[Kontsulta 201804-22];83:12-24. Eskuragarri: http://www.revista-apunts.com/en/library?article=134

9 Juraschek SP, Blaha MJ, Whelton SP, Blumenthal R, Jones SR, Keteyian SJ, Schairer J, Brawner $\mathrm{CA}, \mathrm{Al}-\mathrm{Mallah} \mathrm{MH}$. Physical fitness and hypertension in a population at risk for cardiovascular disease: the Henry Ford Exerclse Testing (FIT) Project. J Am Heart Assoc. 2014 Dec;3(6):e001268.

10 Pérez-Rodrigo C, Ribas L, Serra L, Aranceta J. Preferencias alimentarias, conocimientos y opiniones sobre temas relacionados con alimentación y nutrición. Estudio Enkid. En: Alimentación Infantil y Juvenil. Estudio Enkid. Serra L, Aranceta J (eds.). Barcelona; 2002.

11 Malek R, Gonzalez-Galvez G, El Naggar N, Shah S, Prusty V, Litwak L. Safety and effectiveness of insulin detemir in different age-groups in the A1chieve study.Diabetes Ther.2012;4(1):7790.

12 Romero S, Carrasco L, Sañudo B, Chacón F. Actividad física y percepción del estado de salud en adultos sevillanos [Internet]. Rev Int Med Cienc Act Fís Deporte. 2010 [Kontsulta: 2018-0422];10(39):380-392.

13 Mora M, Villalobos D, Araya G, Ozols A. Perspectiva subjetiva de la calidad de vida del adulto mayor, diferencias ligadas al género y a la práctica de la actividad físico recreativa. MHSalud. 2004;1, 1-12.

14 Miyar Otero L, Zanetti ML, Daguano Ogrizio M. El conocimiento del paciente diabético sobre su enfermedad, antes y después de la implementación de un programa de educación en diabetes. Rev Lat Am Enfermagem. 2008;16(2): 231-237.

15 Valero Zanuy MÁ. Nutrición e hipertensión arterial. Hipertens Riesgo Vasc. 2013; 30(1):18-25.

16 Mazalin Protulipac J, Sonicki Z, Reiner Ž. Cardiovascular disease (CVD) risk factors in older adults- Perception and reality. Arch Gerontol Geriatr. 2015;61(1):88-92.

17 Mosca L, Benjamin EJ,Berra K,Bezanson J L,Dolor RJ ,Lloyd-Jones DM, Newby LK, Piña IL, Roger VL, Shaw LJ, Zhao D,Beckie TM, Bushnell C, D'Armiento J, Kris-Etherton PM, Fang J, Ganiats TG., Gomes AS, Garcia CR, Haan K, Jackson EA, Judelson DR, Kelepouris E, Lavie CJ, Moore A, Nussmeier NA, Ofili E, Oparil S, Ouyang P, Pinn VW, Sherif K, Smith Jr, Sidney C, Sopko G, Chandra-Strobos, Nisha CS, Urbina EM, Vaccarino V, Wenger, NK. Effectiveness- 
based guidelines for the prevention of cardiovascular disease in women-2011 update: A guideline from the American Heart Association. Circulation. 2011;123:1243-1262.

18 Arbonés G, Carbajal B, González- Gross M, Joyanes M, Marques-Lopes I, Martin Mạ, Martínez A, Montero P, Nuñez C, Puigdueta I, Quer J, Rivero M, Roset MaA A, Sánchez-Muniz FJ, Vaquero Mạ. Nutrición y recomendaciones dietéticas para personas mayores. Grupo de trabajo "Salud publica" de la Sociedad Española de Nutrición (SEN). Nutr Hosp. 2003;18(3):109-137.

19 De Vogli R, Kouvonen A, Gimeno D. The influence of market deregulation on fast food consumption and body mass index: a cross-national time series analysis. Bull World Health Organ. 2014;92(2):99-107.

20 Mohan S, Campbell NR. Salt and high blood pressure. Clin Sci (Lond). 2009 Jun 2;117(1):1-11.

21 Yao H, Nabika T. Excess salt increases infarct size produced by photothrombotic distal middle cerebral artery occlusion in spontaneously hypertensive rats. PLoS One. 2014 May 9;9(5):e97109.

22 Correia Horvath JD, Laitano Dias de Castro M, Kops N, Kruges Malinoski N, Friedman Rogéiro. Obesity coexists with malnutrition? Adequacy of food consumption by severely obese patients to dietary reference intake recommendations. Nutr Hosp. 2014;29(2): 92-299

23 De Rufino Rivas P, Redondo Figuero C, Amigo Lanza T, González- Lamuno T, García Fuentes M; Grupo Avena. Desayuno y almuerzo de los adolescentes escolarizados de Santander. Nutr Hosp. 2005;20(3):217-222

24 Watanabe Y, Saito I, Henmi I, Yoshimura K, Maruyama K, Yamauchi K, Matsuo T,Kato T, Tanigawa T, Kishida T, Asada Y. Skipping breakfast is correlates with obesity. J Rural Med. 2014;9(2):51-58.

25 Bustos P, Amigo H, Arteaga A,Acosta AM, Rona RJ. Factores de riesgo de enfermedad cardiovascular en adultos jóvenes. Rev Med Chil. 2003;131(9):973-980.

26 Vázquez-Velázquez V. ¿Cuáles son los problemas psicológicos, sociales y familiares que deben ser considerados en el diagnóstico y tratamiento del paciente obeso? Revista de Endocrinología y Nutrición. 2004; 12 No. 4 Supl. 3: S136-S142.

27 Lauderdale DL, Knutson KL, Yan LL, Rathouz PJ, Hulley SB, Sidney S, Liu K. Objectively measures sleep characteristics among early-middle-aged adults. The CARDIA study. Am J Epedimiol. 2006;164: 5-16.

28 Belo-da Cunha MC, Zanetti ML, Hass VJ. Calidad del sueño en diabéticos tipo 2. Rev. LatinoAm. Enfermagem. 2008;16(5): 850-855-

29 Helleström A, Helleström P, Willman A, Fagerström C.Association between sleep disturbances and leisure activities in the elderly: A comparison between men and women. Sleep Disorders. 2014;2014:595208.

30 Marcos A, Manonelles P, Palacios N, Wárnber J, Casajús JA, Pérez M, Aznar S, Beniro PJ, Martínez-Gomez D, Ortega FB, Ortega E, Urrialde R. Physical activity, hydration and health. Nutr Hosp. 2012;29(6):1224-1239. 